\title{
Hagia Sophia, God's Chosen Ruler, and St. Nicholas: New Perspectives on the Macedonian Dynasty
}

\author{
Brigitte Pitarakis*
}

Hagia Sophia under the Macedonian Dynasty (867-1056) is one of the most fecund topics of interdisciplinary research among Byzantinists. Despite the already large body of literature, it continues to produce a plethora of research opportunities and new perspectives. ${ }^{1}$ In this regard, a set of historical, archaeological, and iconographic sources on Hagia Sophia currently point to reframing the imperial office under the Macedonians based on reassessments of the hagiographical dossier of St. Nicholas and archaeological studies of his pilgrimage shrine in Myra (Demre), Lycia. They do so in their content on the ascent of Basil I (r. 867-886), his founding of a new dynasty, and his invocation of St. Nicholas. Examination of the sources reveal common or related characteristics at Hagia Sophia, the Nea Ekklesia in Constantinople, and the shrine of St. Nicholas in Myra that shed light on the forces behind the promotion of St. Nicholas's cult and his impact on the Macedonians' political ideology.

\section{The Emperor's Crown and Divine Unction}

\section{Reframing the imperial procession}

The tenth-century Book of Ceremonies is the main source documenting protocol for imperial ceremonial entrances and exits at Hagia Sophia. Of interest here is the Macedonian Dynasty and their emperors' use of the chapel of the Holy Well and the passageway (diabatika) outside the chapel of St. Nicholas. ${ }^{2}$

Depending on the church calendar and circumstances, imperial entrances of the Macedonian emperors and their successors were accordingly made through the Beautiful Doors of the southwestern vestibule or the chapel of the Holy Well, which opens onto a passageway leading to the Chalke Gate of the Great Palace. Upon arriving in the narthex, the emperor removed his crown, and after bowing before Lord in another act of humility, he proceeded hand in hand with the patriarch down the nave until reaching the sanctuary screen. At that point, as the patriarch passed through the Holy Doors into the sanctuary, the emperor remained behind, at the omphalion, the square, circle-filled porphyry plaque on the southern end of the nave (fig. 1). After more bowing, the emperor was received by the patriarch in the sanctuary. According to Gilbert Dagron, the emperor's passage through the Holy Doors represented a

\footnotetext{
"Centre national de la recherche scientifique, pitarakis@gmail.com

I would like to thank Stephanos Efthymiadis, Michael Featherstone, and Catherine Jolivet-Lévy who kindly accepted to read the last version of my paper. All errors and conclusions remain mine.

1 See for instance, Bissera V. Pentcheva, Hagia Sophia: Sound, Space, and Spirit in Byzantium (University Park: Pennsylvania University Press, 2017); Natalia B. Teteriatnikov, Justinianic Mosaics of Hagia Sophia and Their Aftermath (Washington, DC: Dumbarton Oaks Research Library and Collection, 2017); Ken Dark and Jan Kostenec, Hagia Sophia in Context: An Archaeological Re-examination of the Cathedral of Byzantine Constantinople (Oxford: Oxbow Books, 2019); Alicia Walker, "The Emperor at the Threshold: Making and Breaking Taxis at Hagia Sophia," in The Emperor in the Byzantine World: Papers from the Forty-Eighth Spring Symposium of Byzantine Studies, ed. Shaun Tougher (London: Routledge, 2019), 281-321.

2 Constantin Porphyrogénète. Le Livre des Cérémonies, ed., Gilbert Dagron (*) and Bernard Flusin in coll. with Michel Stavrou, I-V, 6 vols., CFHB 52 (Paris: Amis du Centre d'histoire et civilisation de Byzance, 2020), 1:58-61, 1:330-333; 4.1:95-96, 4.1:173-174, 4.1:347-348; 5:95; Constantini Porphyrogeniti imperatoris De cerimoniis aulae byzantinae libri duo, ed. l. l. Reiske, CSHB (Bonn, 1829), esp. vol. 1, chap. 34 and 1:181-183; in English, Anne Moffat and Maxeme Tall, trans., Constantine Porphyrogennetos: The Book of Ceremonies, 2 vols., Byzantina Australiensia 18 (Canberra: Australian Association for Byzantine Studies, 2012). For a recent discussion on the archaeological structures, see Dark and Kostenec, Hagia Sophia in Context, 35, fig. 23, 75-76 (here diabatika is translated as "corridor").
} 
166

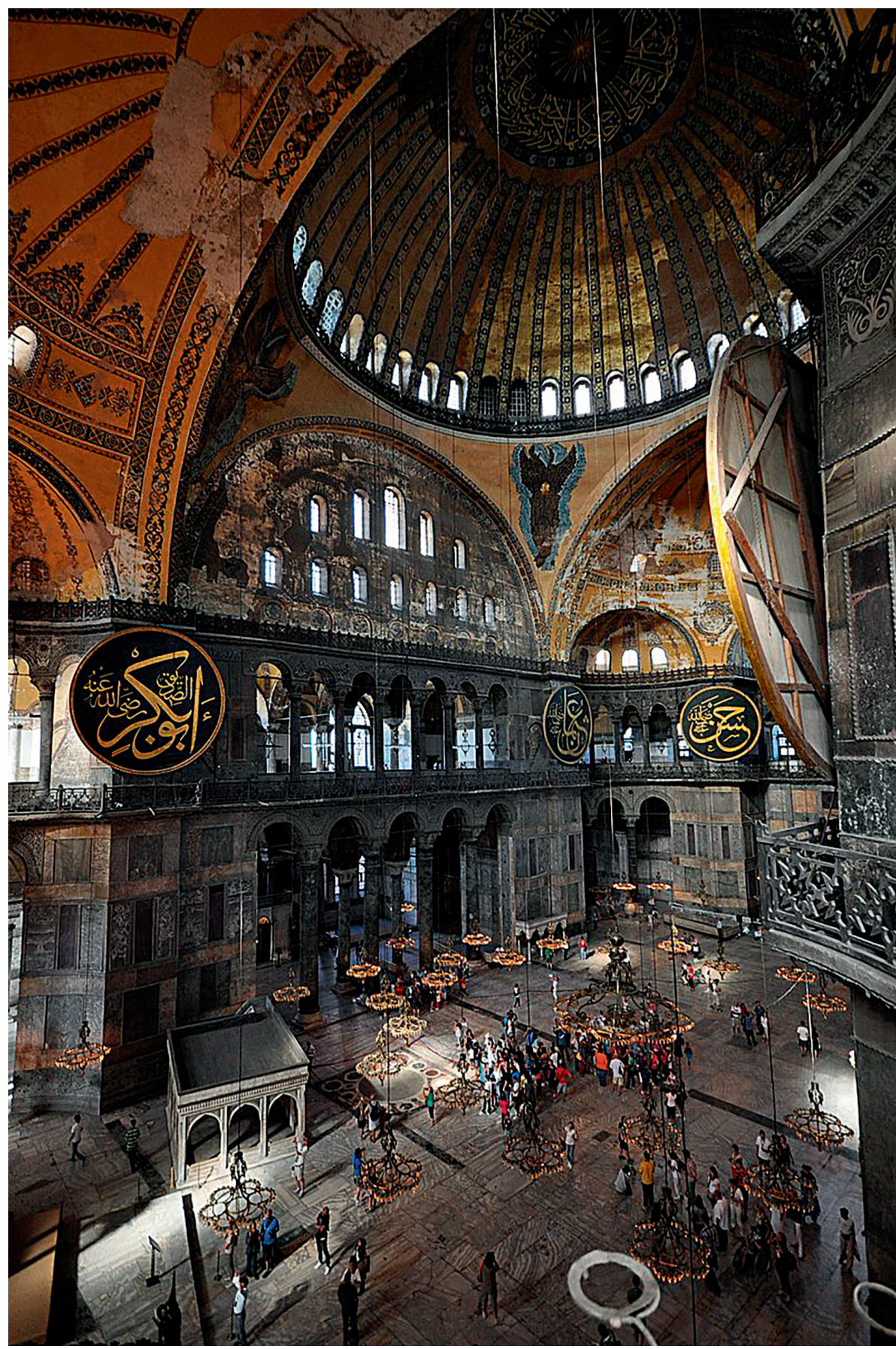

temporary transformation in his status. That is, while in the sanctuary, he participated in the liturgy as a "quasi-priest" or "quasi-bishop."

To exit the sanctuary, the emperor had a choice of two itineraries. From the Holy Doors, he could proceed westward, back toward the narthex, where he had removed his crown, ${ }^{4}$ or he could use the door on the northern side of the sanctuary, by which he entered the passageway
Figure 1: Hagia Sophia, southern nave, east-west view. Photograph: Jorge Láscar, 2012. Wikimedia Commons, accessed October 16, 2020. 
Figure 2: Hagia Sophia, eastern end at ground level, as envisioned by Eugène Antoniades

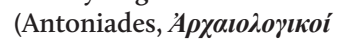

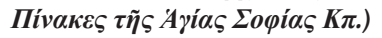

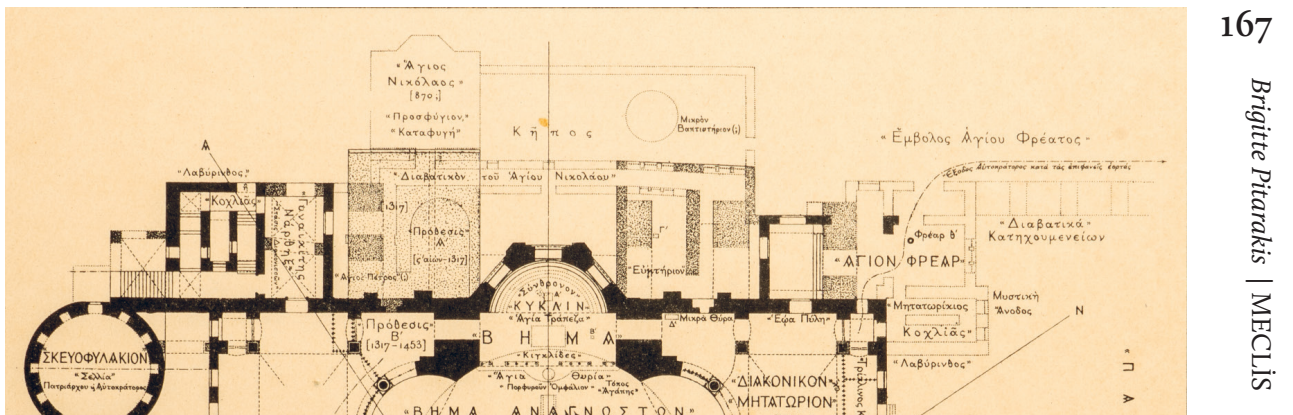

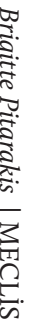

St. Nicholas (diabatika tou Nikolaou). The passage served as an exterior vestibule to the chapel of St. Nicholas, at the northeastern corner of Hagia Sophia, and continued without interruption to the chapel of the Holy Well, at the southeastern corner of the building (fig. 2). 5 At the Holy Well, the patriarch returned the emperor's crown to him. This ritual was performed behind curtains, as was removal of the crown upon entering the building.

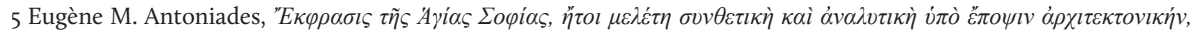

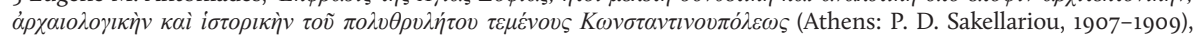
2:163-160 and 2:169-85; Cyril Mango, The Brazen House: A Study of the Vestibule of the Imperial Palace of Constantinople (Copenhagen: Munksgaard, 1959), 67-72, 76-77, 81. See also Ernest Mamboury, "Sainte-Sophie, le sanctuaire et la solea, le mitatorion, la Sacré puits, le passage de St. Nicolas," Atti del V Congresso di Studi bizantini. II. Archeologia e storia dell'arte. Liturgia e musica. Cronaca del congresso, Roma 20-26 settembre, 1936 (Rome: Tip. Del Senato del dott. G. Bardi, 1940), 197-209. 
168
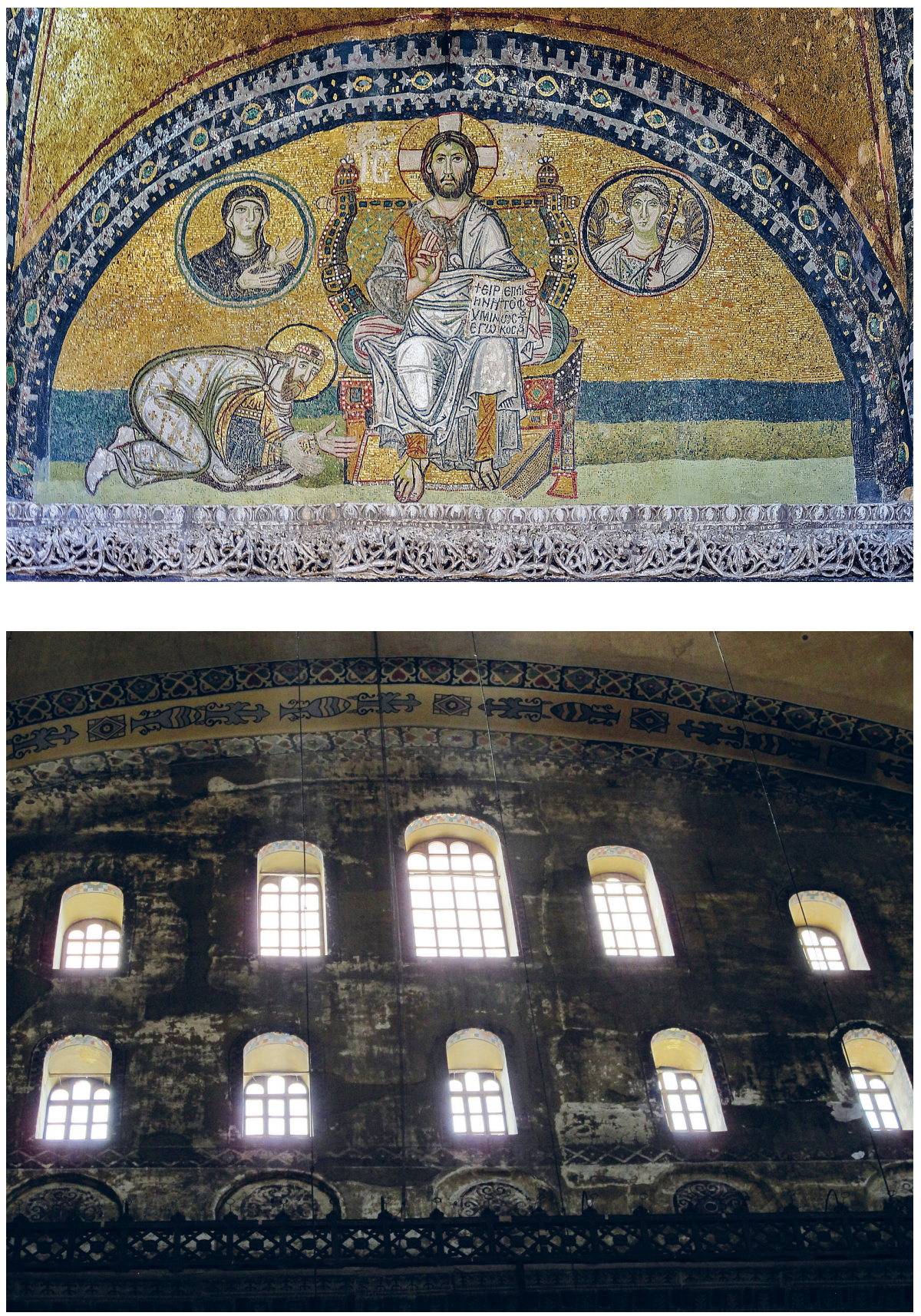

Scholarly discussion of imperial ritual in Hagia Sophia has tended to focus on the famous lunette mosaic above the narthex door that depicts an emperor, thought to represent Leo VI (r. 886-912), in proskynesis before the throne of Christ (fig. 3). ${ }^{6}$ Although most of the south tympanum mosaics have not been preserved (fig. 4), and the structures behind the sanctuary of Hagia Sophia were hidden by the addition of buttresses, one can still visually reconstruct the environment surrounding imperial processions. Ascertaining the reason the chapel of

6 The alternative that this mosaic may represent Basil I was not dismissed in scholarship. See Leslie Brubaker, Vision and Meaning in Ninth-Century Byzantium: Images as Exegesis in the Homilies of Gregory of Nazianzus (Cambridge: Cambridge University Press, 1999), 149-150. The fact that Leo Vl struck some gold coins (nomismata) bearing a true portrait instead of an undifferentiated imperial figure may perhaps strengthen the link of the lunette mosaic with Leo Vl. See Philip Grierson, Byzantine Coinage (Washington, D.C.: Dumbarton Oaks, Trustees for Harvard University, 1999), 9 .
Figure 3: Hagia Sophia, narthex with lunette mosaic above the imperial door depicting an emperor prostrated before the throne of Christ. Photograph: Myrabella. 2013. Wikimedia Commons, accessed October $16,2020$.

Figure 4: Hagia Sophia, view of the south tympanum. Photograph: Kerim Altuğ, January 2013. 
St. Nicholas was chosen as a path for the emperor's exit from the sanctuary leads one to look at the Nea Ekklesia, the church built by Basil I in the Great Palace precinct and inaugurated by Patriarch Photios in May 88o. The church is dedicated to Christ, the prophet Elijah, the archangel Gabriel (and later Michael), the Virgin Mary, and St. Nicholas. ${ }^{7}$

The mosaic of Nicholas on the south tympanum of Hagia Sophia appears to have been one element in an integrated "network" for invoking the saint on whom Basil and his dynastic successors came to rely on earth and in anticipation of death. The row of church fathers and patriarchs on Hagia Sophia's two tympana were still visible at the time of the restoration work conducted by Gaspare Fossati (1809-1883) and his brother Giuseppe Fossati (1822-1891) under a commission from Abdülmecid (r. 1839-1861). The brothers' watercolors and those by the Prussian engineer Wilhelm Salzenberg (1803-1887) reveal how they once looked. On the south tympanum, one finds St. Nicholas, who has been honored as a church father, positioned sixth in the row, from east to west, along with Sts. Anthimos, Basil, Gregory the Theologian, Dionysios, and Gregory the Illuminator of Armenia. ${ }^{8}$ The first figure in the row is unknown (fig. 5-6). This row of figures faces the row of church fathers and patriarchs on the north tympanum consisting, from west to east, of Sts. Ignatios the Younger, Methodios, Gregory the Thaumaturge, John Chrysostom, Ignatios Theophoros, Cyril, and Athanasios. ${ }^{9}$

The tympana may be attributed to a series of repairs undertaken by Basil I and possibly necessitated by the earthquake of 869 . The redecoration of the mosaics was conceived and begun under Basil $\mathrm{I}$, and those on the south tympanum might have been started before his death in 886 and completed during the early reign of his son and immediate successor, Leo VI. ${ }^{10}$ The latter also had a personal attachment to St. Nicholas as evidenced by his homily to the saint in which he thanks him for the cure to his sufferings and assistance at the helm of the empire. ${ }^{11}$ As the opus sectile of the omphalion has been attributed to Basil I (fig. 7), ${ }^{12}$ the chapel of St. Nicholas might well also fall under the same reign, but the prospect that it may have been constructed at the initiative of the saint's namesake Nicholas I Mystikos (r. 901-907 and 912-925), during his first patriarchate, cannot be dismissed. ${ }^{13}$

However, in the tenth-century typikon of the Great Church, the synaxis for St. Nicholas was held at the Great Church. Here, the chapel of St. Nicholas ta Basilidou is not identified by name. ${ }^{14}$ In the twelfth century, the chapel was regarded as a place of asylum or refuge for

7 See Paul Magdalino, "Le culte de saint Nicolas à Constantinople," En Orient et en Occident, le culte de saint Nicolas en Europe ( $X^{e}-X X I^{e}$ siècle): Actes du colloque de Lunéville et Saint-Nicolas-de-Port, 5-7 décembre 2013, ed. Véronique Gazeau, Catherine Guyon, and Catherine Vincent (Paris: Les Éditions du Cerf, 2015), 41-56; Magdalino, "Observations on the Nea Ekklesia of Basil l," JÖB 37 (1987): 51-64; Magdalino, "Basil l, Leo Vl, and the Feast of the Prophet Elijah," JÖB 38 (1988): 193-196.

8 The association of St. Nicholas to church fathers is a regular feature of Cappadocian decorative programs from the late ninth to early tenth century. Among other examples, see Balkan Deresi 4 between ibrahimpaşa and Ortahisar, Holy Apostles in Sinassos, Timios Stavros near Sinasos. See Catherine Jolivet-Lévy in coll. with Nicole Lemaigre Demesnil, La Cappadoce: Un siècle après G. de Jerphanion, 2 vols. (Paris: Geuthner, 2015), 1, 175, 187, 193.

9 See also 600 Ylllk Ayasofya Görünümleri ve 1847-49 Fossati Restorasyonu, exhibition catalogue, ed. Volker Hoffmann (Istanbul: T.C. Kültür Bakanlığı Anıtlar ve Müzeler Genel Müdürlüğü, 200o), 115-116; Wilhelm Salzenberg, Altchristliche Baudenkmale von Constantinopel vom V. bis XII. Jahrhundert: im Anhange des Silentiarius Paulus Beschreibung der Heiligen Sophia und des Ambon (Berlin: Verlag von Ernst \& Korn, 1854), pl. XXIX.

10 Cyril A. Mango, Materials for the Study of the Mosaics of St. Sophia at Istanbul (Washington, D.C.: Dumbarton Oaks Research Library and Collection, 1962), 48-57, drawing 1II; Roland J. Mainstone, "The Reconstruction of the Tympana of St. Sophia in Istanbul," DOP 23-24 (1969-1970): 353-368; Cyril Mango and Ernest J. W. Hawkins, "The Mosaics of St. Sophia at lstanbul: The Church Fathers on the North Tympanum," DOP 26 (1972): 6-8, 36-41.

11 See discussion in Bernard Flusin, "L'empereur hagiographe: Remarques sur le rôle des premiers empereurs macédoniens sur le culte des saints," in L'empereur hagiographe: Culte des saints et monarchie byzantine et post-byzantine, ed. Petre Guran and Bernard Flusin (Bucharest: Colegiul Noua Europă, 2001), 35-36.

12 See Silvia Pedone, "The Marble Omphalos of Saint Sophia in Constantinople: An Analysis of an Opus Sectile Pavement of Middle Byzantine Age," in 11th International Colloquium on Ancient Mosaics, ed. Mustafa Şahin (Istanbul: Ege Yayınlar1, 2011), 749-768.

13 Antoniades hypothesizes that the chapel of St. Nicholas may have been built by Basil the Macedonian; see

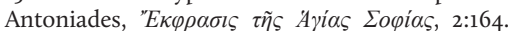

14 Le typicon de la Grande Église: Ms. Sainte-Croix no. 40, Xe siècle, ed. Juan Mateos, vol. 1, Le cycle des douze mois (Rome: Pontificium Institum Studiorum Orientalium, 1962), 124. For wider bibliography on St. Nicholas ta Basilidou, see Maria Vaiou, "The Byzantine churches founded by the emperor Constantine (324-37)," accessed November 18, 2020, http://www.irenik.org/no-254-2019/. 

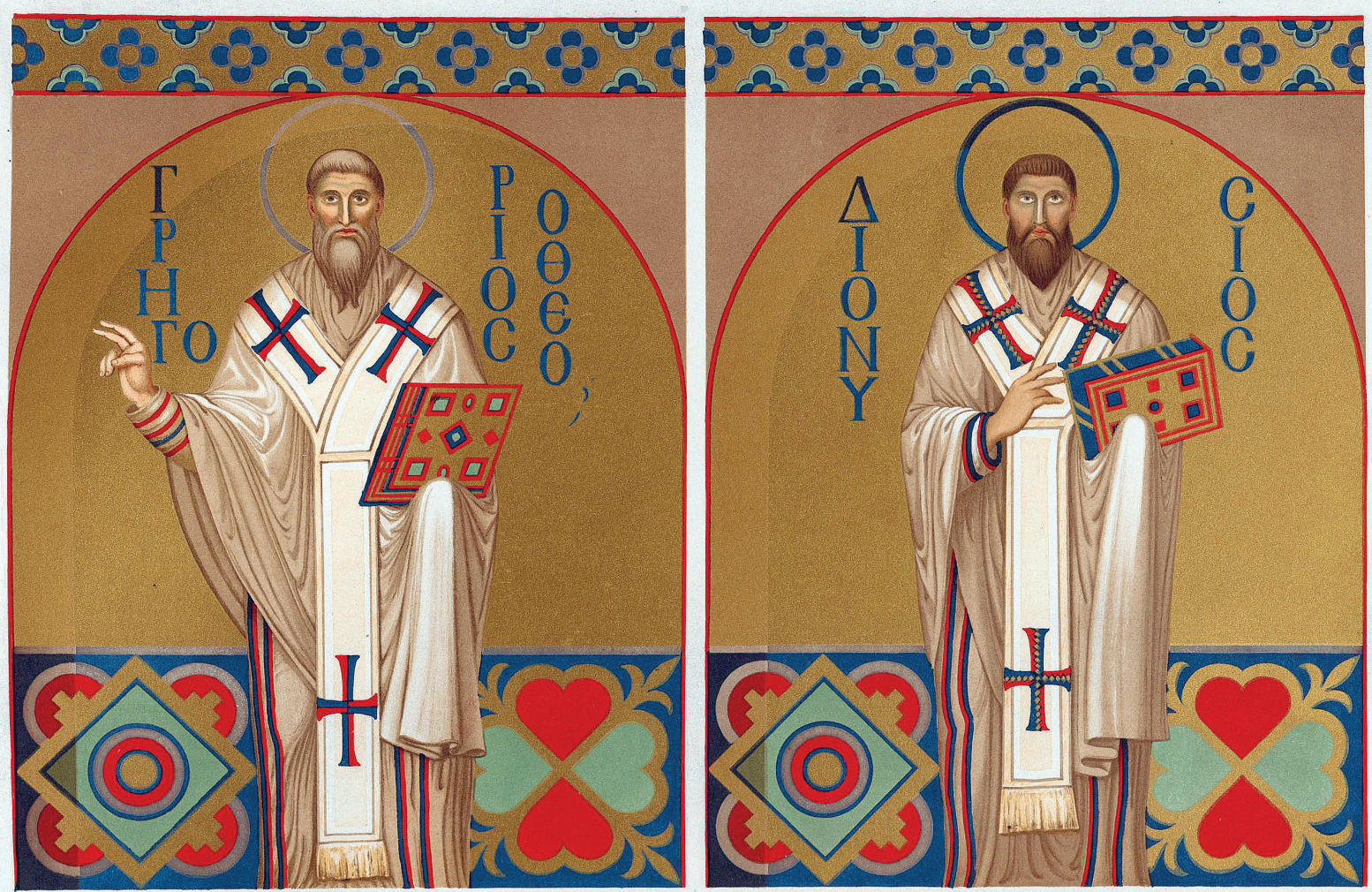

GREGORIOS THEOLOCOS

DIONYSIOS.
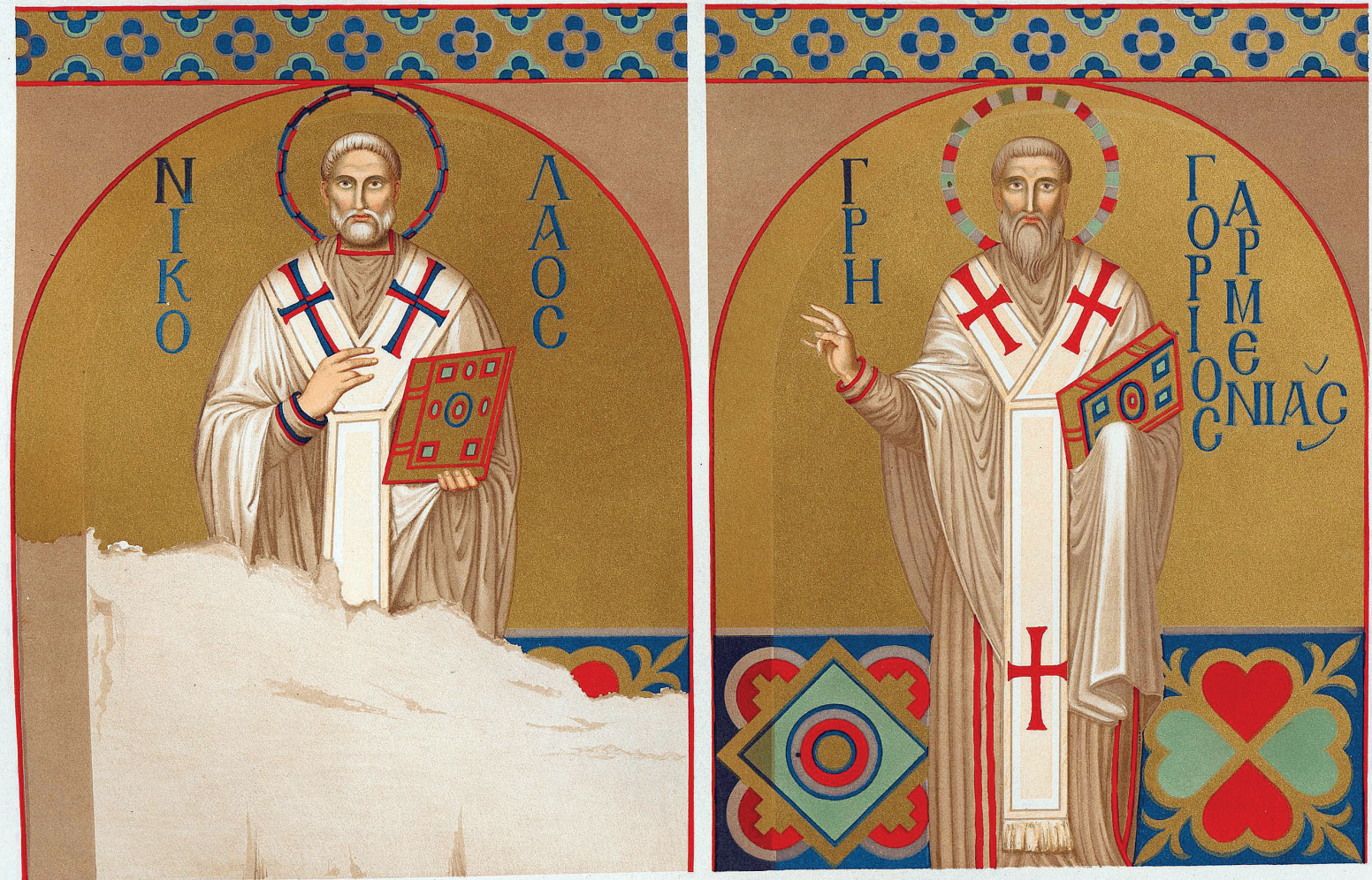

NIKOLAOS

GREGORIOS ARMENIOS

MOSAIK-BILDER AN DER SÜDSEITE DES SCHIFFES

Figure 5: Hagia Sophia, watercolor of the standing church fathers on the south tympanum (Salzenberg, Alt-christliche Baudenkmale, pl. XXIX). 
Figure 6: Hagia Sophia, drawing of the south tympanum (Mango, Materials, drawing III).

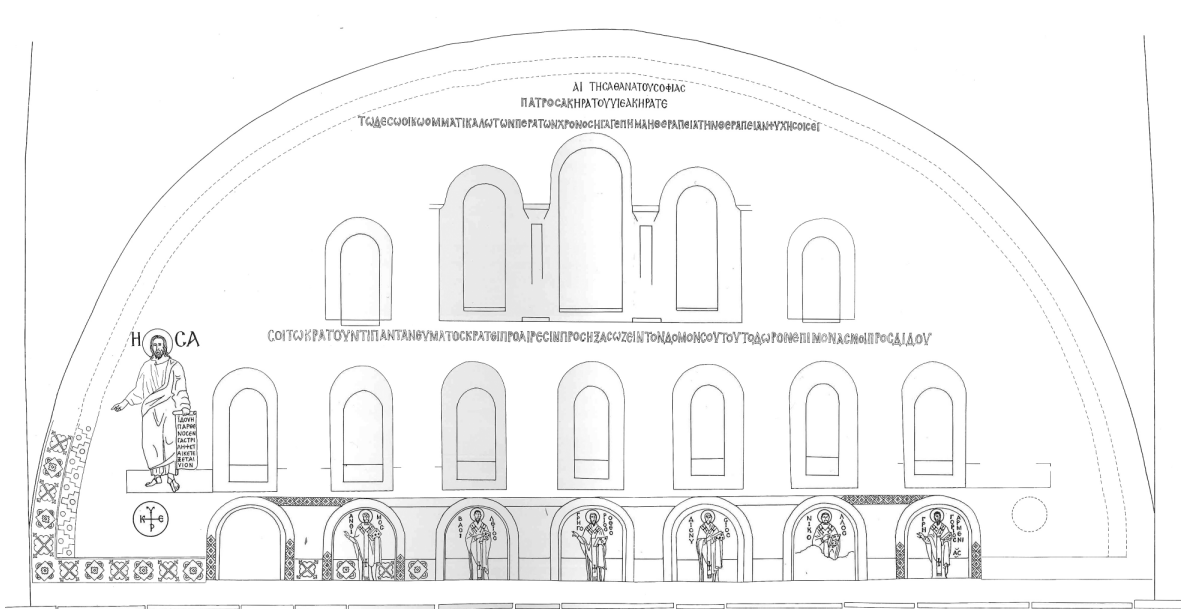

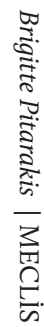

Figure 7: Hagia Sophia, the omphalion. Photograph: Tayfun A. Öner, January 2015.

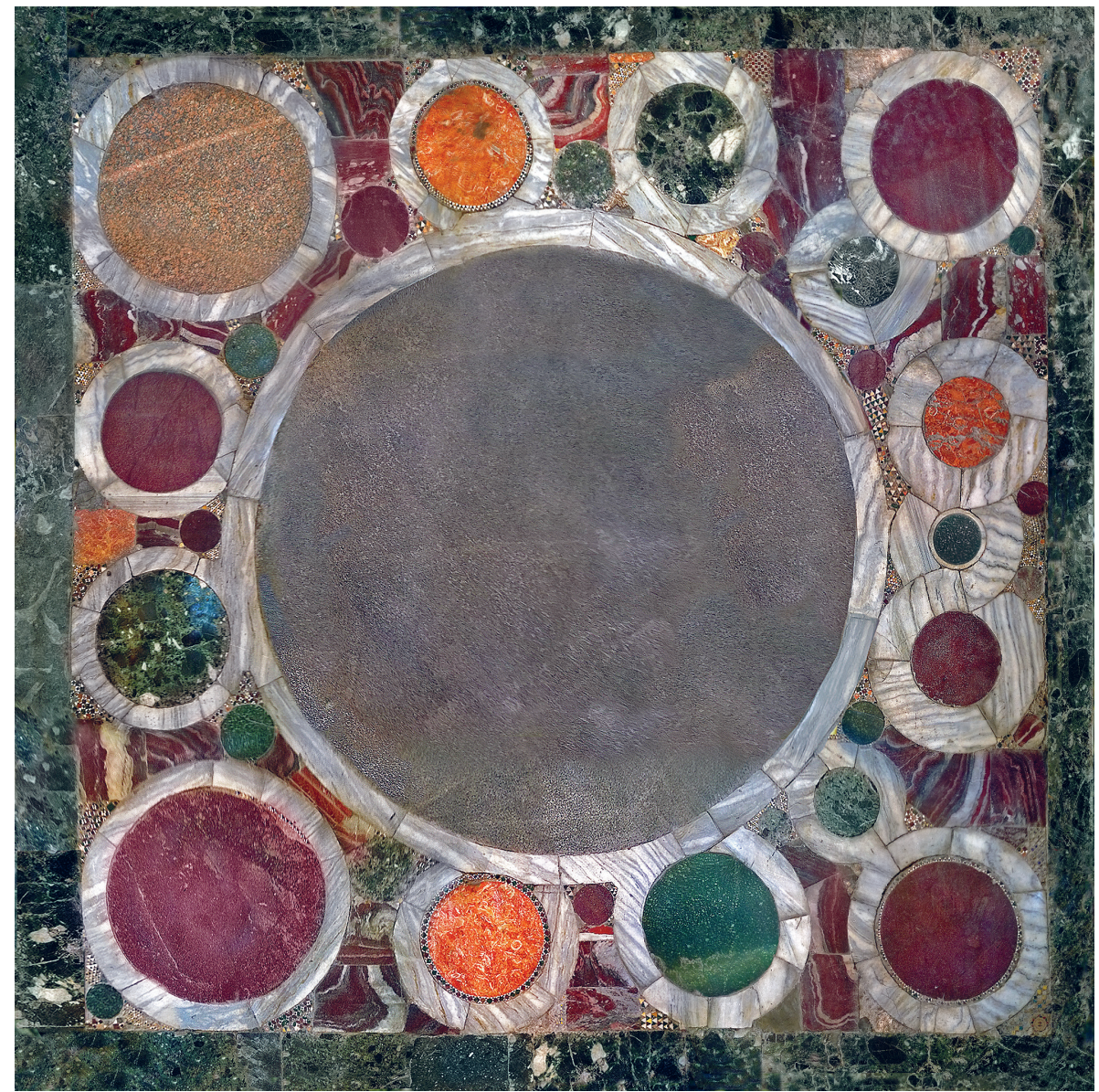



desire for penance might have played some role. One should not forget that Basil, in seizing the throne, had murdered Michael III. Within the Great Church before the reign of Basil I, asylum had also been granted in the sanctuary and elsewhere. ${ }^{16}$

The two rows of standing church fathers and patriarchs flanking each side of the nave represent a heavenly counterpart to the earthly procession below. St. Nicholas-witnessing the emperor's transformative ritual upon entering and exiting the sanctuary-perhaps signifies the Macedonian emperor's privileged place in the eschatological future. An apocalyptic reading was also proposed by Paul Magdalino, who views the priestly king as the perfect complement to the reigning saint in the eternal Kingdom of God. ${ }^{17}$

This interpretation fits with the image of the last emperor, who according to the apocalypses, a popular literary genre of the period, would depart for Jerusalem to lay his crown on the reconstituted cross of Golgotha and return his power to Christ with the Second Coming. Dagron proposed viewing the emperor's removal of his crown upon his entrance to the narthex as a prefiguration of the last emperor of Byzantium. ${ }^{18}$ On the lunette mosaic above the narthex door, the model of the emperor in proskynesis might be the penitence of David, highlighted in the illuminated manuscript of the Homilies of Gregory of Nazianzus (Paris gr. 510), which Photios commissioned for Basil. In the images, David is prostrate before Nathan and in the towering presence of the chastising archangel Michael, identified as archistrategos (fig. 8). ${ }^{19}$

\section{Hagia Sophia, the Nea, and St. Nicholas of Myra: The Myron Connection}

The ambulatory at the eastern end of Hagia Sophia was invested with strong symbolic meaning, promoting the restoration of the golden age of Justinian. The relics preserved at the Holy Well heighten the salvific message of the myron of St. Nicholas and strengthen the spiritual link between the Byzantine capital and Myra.

\section{The Holy Well and Elijah}

According to the Narrative on the Construction of Hagia Sophia, or Diegesis, a text associated with the reign of Basil I, Justinian had brought four trumpets from Jericho and displayed them at the chapel of the Holy Well, also called Jacob's well, referencing where Jesus had met the Samaritan woman. ${ }^{20}$ The material of the trumpets is not specified in the text, but the Scriptures say that they were ram horns (Joshua 6:4). The Gospel episode (John 4:4-42) in which Jesus engages the Samaritan woman at the well was considered a prefiguration of baptism, and the discovery of a real well in the chapel heighten this significance. The trumpets, said to be imitations of those that the angels blew when the walls of Jericho fell, symbolized the regathering of the people of God around the redemptive power of baptism. The Holy Well was also the site of an icon of Christ that, according to a legend revived during iconoclasm, had bled after being stabbed by a Jew. ${ }^{21}$ This symbolic combination of Christ's blood and baptismal water at the Holy Well obviously imparted a eucharistic message.

At least one of the trumpets of Jericho was later moved to the Nea, which under the Macedonian emperors became a repository of Old Testament relics. Other objects in the church

15 See Ruth Macrides, "Killing, Asylum, and the Law in Byzantium," Speculum 63, no. 3 (1988): 514.

16 The Life of the Patriarch Tarasios by Ignatios the Deacon (BHG 1698). Ed., trans., and intro. Stephanos Efthymiadis (Aldershot: Ashgate, 1998), 34-35, 186, chap. 34. See also John Cotsonis, "The Virgin and Justinian on the Seals of the Ekklesiekdikoi of Hagia Sophia," DOP 56 (2002): 41-55.

17 Paul Magdalino, "The Year 1000 in Byzantium," in Byzantium in the Year 10oo, ed. Paul Magdalino (Leiden: Brill, 2003), 250-256.

18 Dagron, Emperor and Priest, 104. On the last emperor, see András Kraft, "The Last Roman Emperor 'Topos' in the Byzantine Apocalyptic Tradition," Byzantion 82 (2012): 213-257.

19 Brubaker, Vision and Meaning, fol. 143v, fig. 19, 74, 354. See also Élias Antonopoulos, "Métanoia: La personne, le sentiment et le geste," DChAE 41 (2002): 15-19.

20 Diegeseis 4.22-23, Albrecht Berger, Accounts on Medieval Constantinople: The Patria (Cambridge, MA: Harvard University Press, 2013), 261. About the date of the text, see Stephanos Efthymiadis, "Diegeseis on Hagia Sophia from Late Antiquity to Tenth-Century Byzantium," Byzantinoslavica 73 (2015): 16-18.

21 Efthymiadis, "Diegeseis on Hagia Sophia," 18-22. 


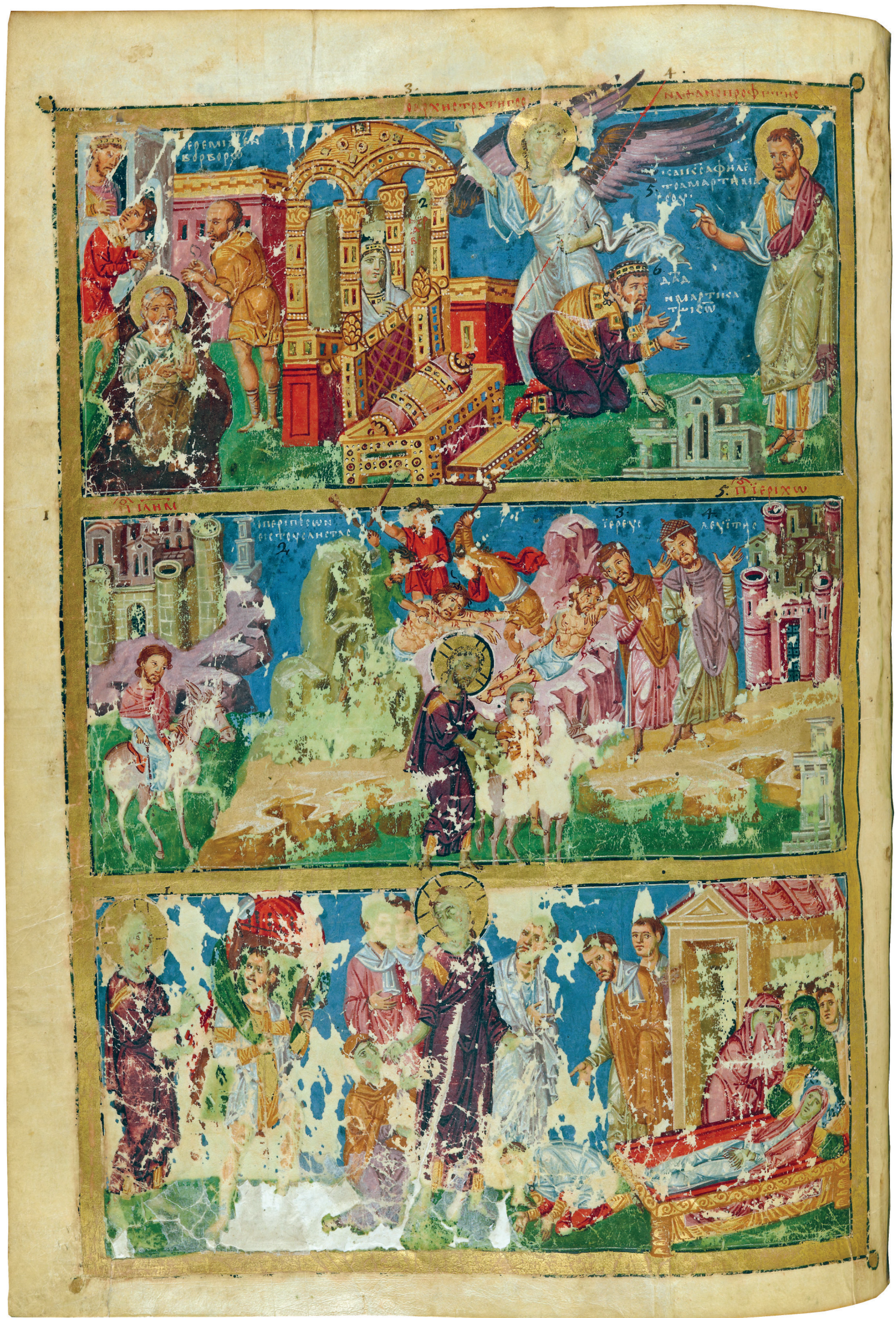

Figure 8: Penitence of David, from the Homilies of Gregory of Nazianzus, Paris gr. 510, fol. 143v. Bibliothèque nationale de France. 
included the horn of Abraham's ram, which like the trumpets of Jericho served to sound the hour of Resurrection, the horn with which Samuel anointed David king, and the sheepskin cloak of Elijah the dynastic saint of the Macedonians. ${ }^{22}$

Basil, the founder of the dynasty, had been a peasant from Thrace. As Basil prepared to depart for Constantinople in search of good fortune, Elijah appeared to his mother and announced her son's inevitable ascension to the imperial throne. ${ }^{23}$ After a spectacular rise in the court of Emperor Michael III (r. 842-867), Basil killed his co-emperor to seize sole control and begin establishing the Macedonian Dynasty. The Old Testament relics in the Nea point to Basil I as embodying the chosen people of the Old Testament, as their elevation, like his ascent to the throne, was God-given.

During Justinian's reign the spring of Elijah had been a major pilgrimage site in Jericho. In the Old Testament, Elijah embodies divine justice. According to the Gospel of Mark, Elijah returns to earth in the person of John the Baptist, who is presented as the forerunner of the Messiah Jesus, heralding the Son of God's arrival to inaugurate the Kingdom of God in power on earth. ${ }^{24}$ The myron of St. Nicholas from Myra, when added to the water of the Holy Well, enhanced the baptismal message of the ritual of crowning the emperor during his visits to the chapel before exiting Hagia Sophia. The gold coin of Emperor Alexander (r. 912-913), brother of Leo VI, the only known numismatic type of John the Baptist, who is shown blessing the emperor, offers a rare pictorial testimony to the baptismal connotation of the divine unction conferred on the porphyrogennetoi (those born in the purple). ${ }^{25}$ The baptismal message of anointing highlights the idea of the God-chosen emperor ruling over his chosen people. ${ }^{26}$

\section{St. Nicholas of Myra}

Myron, the flowing virtue of St. Nicholas, was discovered at his grave in Myra sometime in the ninth century. The future patriarch Methodios $(843-847)^{27}$ authored what is thought to be the first Life of the saint, a short compilation in which he mentions the miracle-working myron. Methodios also devoted a praise (enkomion) to the saint in which he gives the myron prominence. ${ }^{28}$ The canons of Joseph the Hymnographer, appointed by Basil I as sacristan (skeuophylax) of Hagia Sophia, is another early testimony on the cult of St. Nicholas. ${ }^{29}$

In the sixth century, before the apparition of the myron, St. Nicholas of Myra had inspired an oil cult. The sacred oil distributed to pilgrims may have come from a lamp burning above the saint's grave, and there may also have been a process of sanctification through contact with the relics. Methodios, in his Life, compares the saint to a "lamp that is corporeally covered

22 Magdalino, "Observations on the Nea Ekklesia of Basil I"; Magdalino, "Basil I, Leo Vl, and the Feast of the Prophet Elijah."

23 Chronographiae quae Theophanis Continuati nomine fertur liber quo Vita Basilii imperatoris amplectitur, ed. Ihor Ševčenko, CFHB 42 (Berlin: De Gruyter, 2011), 83.9-10.

24 The bibliography is vast. Among others, see Markus Öhler, "The Expectation of Elijah and the Presence of the Kingdom of God," Journal of Biblical Literature 118, no. 3 (1999): 461-476; SJ Nortje, "John the Baptist and the Resurrection Traditions in the Gospels," Neotestamentica 23, no. 2 (1989): 349-358.

25 Nicole Thierry, "Le Baptiste sur le solidus d'Alexandre (912-913)," Revue numismatique 34 (1992): 237-241; Byzance: L'art byzantin dans les collections publiques françaises (Paris: Éditions de la Réunion des musées nationaux, 1992), no. 310 .

26 See Catherine Jolivet-Lévy, "L'image du pouvoir dans l'art byzantin sous la dynastie macédonienne (867-1056)," Byzantion 57 (1987): 442-443; Meredith L. D. Riedel, Leo VI and the Transformation of Byzantine Christian Identity: Writings on an Unexpected Emperor (Cambridge: Cambridge University Press, 2018), 154-174.

27 It would seem that Methodios drew his monastic name from Pseudo-Methodios, pseudepigraphic author of an apocalypse, falsely attributed to the fourth-century church father Methodios of Patara (or Olympos), in Lycia. In this text, one finds the earlier occurrence of the topos of the Last Roman Emperor; see Kraft, "The Last Roman Emperor," $213-214$.

28 See Ihor Ševčenko, "Hagiography of the lconoclast Period," in Ideology, Letters and Culture in the Byzantine World (London: Variorum Reprints, 1982), chap. 5. On Methodios's hagiographic activity, see Stephanos Efthymiadis, "Hagiography from the 'Dark Age' to the Age of Symeon Metaphrastes (Eighth-Tenth Centuries)," in The Ashgate Research Companion to Byzantine Hagiography. I: Periods and Places, ed. Stephanos Efthymiadis (Farnham: Ashgate, 2011), 103-106.

29 Nancy Patterson Ševčenko, "Canon and Calendar: The Role of a Ninth-Century Hymnographer in Shaping the Celebration of Saints," in Byzantium in the Ninth Century: Dead or Alive? Papers from the Thirtieth Spring Symposium of Byzantine Studies, ed. L. Brubaker (Aldershot: Ashgate, 1998), 101-114; reprinted in Nancy Patterson Ševčenko, The Celebration of the Saints in Byzantine Art and Liturgy (Farnham: Ashgate, 2013). 
with a slab" and a "wick that has been partaken."30 Light is a common metaphor for Nicholas, investing him with a strong salvific message. ${ }^{31}$ Here, however, the setting may also allude to the actual vessel hung above the saint's sarcophagus.

The apparition of myron induced a reorganization of the cult around St. Nicholas's grave. This occurred in a political, ideological, and economic environment favorable to the complete rebuilding of the original sixth-century basilica, which was destroyed in the eighth century during Arab raids or an earthquake. The new shrine, in the shape of a domed basilica, incorporated two annexes at the northeast and southeast corners, which are remains from the original basilica. ${ }^{22}$ The layout strikingly parallels the chapels of St. Nicholas and the Holy Well in Constantinople.

Urs Peschlow suggests that the reconstruction took place in the eighth century, with renovations in the ninth. ${ }^{33}$ The coins and other evidence from excavations conducted under the direction of Yıldız Ötüken and pursued by Sema Doğan point to a date in the ninth or tenth century for the rebuilding in the form of a domed basilica. ${ }^{34}$ The architectural layout of the Nea, with its five domes, may have served as model for the shrine in Myra. Ongoing archaeological excavations will bring to light additional information and answers.

\section{Holy Oil and Politics}

As noted, from the south tympanum of Hagia Sophia, St. Nicholas, in the company of the other church fathers, safeguards the emperor's progression toward the sanctuary and then meets him again immediately outside the sanctuary, in the chapel dedicated to him, on his way to the chapel of the Holy Well. Within the sanctuary, St. Nicholas provides the temporary sacerdotal unction of the emperor, while at the Holy Well he confirms his Davidic unction. The divine appointment of Nicholas to fill the vacant episcopal throne of Myra, reported in his Life, is evocative. According to Methodios, a supernatural, disembodied voice had conveyed Nicholas's name to the council of bishops. Proclaiming Nicholas the "ointment-receiving vessel of the all-holy and life-giving Spirit,"35 Methodios compares the grace bestowed upon him with the anointing of David. ${ }^{36} \mathrm{~A}$ similar story in the Life of Basil I explains his own ascension to the imperial throne. ${ }^{37}$

Basil I had the pretension of building a dynasty upon his accession. Davidic unction strengthens his lineage with Constantine the Great, an alignment promoted throughout his reign. ${ }^{38}$

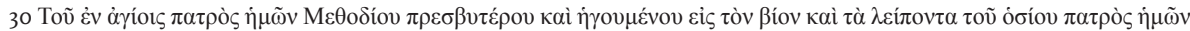

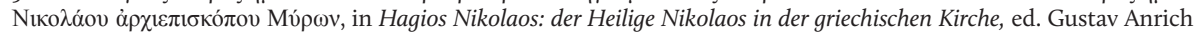
(Leipzig: B. G. Teubner, 1913), 1:141.1-15 and 2:546; English translation of the passage and discussion in D. Krausmüller, "Showing One's True Colours: Patriarch Methodios on the Morally Improving Effect of Sacred Images," BMGS 40 , no. 2 (2016): 298-306.

31 See Catherine Jolivet-Lévy in collaboration with Nicole Lemaigre Demesnil and Georges Kiourtzian, "Bezirana kilisesi (Cappadoce): Un exceptionnel décor paléologue en terres de Rūm. Nouveau témoignage sur les relations entre Byzance et le sultanat," Zograf 41 (2017): 136-137.

32 The northeast annex was discovered during the excavations conducted by Y1ldiz Ötüken in the 1990s. These are two interconnected square domed rooms $\left(\mathrm{C}_{1}\right.$ and $\left.\mathrm{C}_{2}\right)$ communicating with the sanctuary. The soil in the eastern room $\left(C_{2}\right)$ had been soaked with a fragrant substance that chemical analysis revealed to be similar in composition to the myrtle native to Myra. In light of this testimony, and a system of thin pipes that Ötüken unearthed running beneath the room, she suggested $C_{2}$, built in the sixth century, as the site of Nicholas's grave. Semiha Y1ldız Ötüken, "Aziz Nikolaos Kilisesi Kazı Çalışmaları 1989-2009," in Aziz Nikolaos Kilisesi Kazıları, 1989-2009, ed. Sema Doğan and Ebru Fatma Findik (Istanbul: Homer Kitabevi, 2018), 77-87. Another view, grounded in the typology of relic chapels in Myra, and the presence of an arcosolium grave in the apsis, locates the grave at the second southeastern chapel. See Philipp Niewöhner, "The Grave of St Nicholas," in Byzantine Anatolia, ed. Engin Akyürek and Koray Durak (lstanbul: Yapı Kredi Publications, forthcoming 2021); Niewöhner, "Neues zum Grab des hl. Nikolaus von Myra," JAC 46 (2003): 119-133. Many thanks to Sema Doğan and Philipp Niewöhner, who kindly helped me clarify various details about St. Nicholas of Myra.

33 Urs Peschlow, "Die Architektur der Nikolaoskirche in Myra," in Eine lykische Metropole in antiker und byzantinischer Zeit, ed. Jürgen Borchard, Istanbuler Forschungen 30 (Mainz: Philipp von Zabern, 1975), 347.

34 For a recent reappraisal and earlier bibliography, see Sema Doğan, "Mimari Plastik Buluntular: Litürjik Kuruluşlar ve Litürjik Mekânlar ile İlişkisi," in Doğan and Fındık, Aziz Nikolaos Kilisesi Kazıları, 306, 318. See also Çiğdem Alas, "Opus Sectile Zemin Panoları ve Duvar Kaplamaları," in Doğan and Fındık, Aziz Nikolaos Kilisesi Kazıları, 266-267. 35 Hagios Nikolaos, ed. Anrich, 1:141, chap. 1.

36 Hagios Nikolaos, ed. Anrich, 1:147-148, chap. 17.

37 Vita Basilii, 9.7-20.

38 See Athanasios Markopoulos, "Constantine the Great in Macedonian Historiography: Models and Approaches," in New Constantines: The Rhythm of Imperial Renewal in Byzantium, 4th-13th Centuries, ed. Paul Magdalino (Aldershot: Ashgate, 1994), 159-170; Brubaker, Vision and Meaning in Ninth-Century Byzantium, 150-155. 
176 Two dream episodes in the Life of St. Nicholas involve the saint visiting Constantine the Great, who appears as his contemporary. The purpose of these visits was not related to issues of faith. Rather, the saint intervened to provide the emperor divine advice in matters of state rule, establishing a privileged link between them. In the Praxis de stratelatis episode, one of the earliest known miracles of St. Nicholas, he convinces the emperor to release three generals who had been falsely accused of treason and sentenced to death. ${ }^{39}$ In the second episode, ascribed to the ninth or tenth century, ${ }^{40}$ he intervenes on behalf of the habitants of Myra to release them from unjust taxation.

The prestigious lineage of Basil I, probably concocted by Photios, ${ }^{41}$ also allows tying the above episodes to the Macedonians' use of legal reforms as a tool for establishing their legitimacy. ${ }^{42}$ The link between the bishop of Myra and the founder of the Byzantine Empire in the exercise of power serves as the model for Photios's Eisagoge/Epanagoge, the law book he compiled sometime between 879 and 886, where law is called a "divine invention." In this light, the emperor, although considered the legitimate authority, lacks true independence and serves to execute the legislation of Christ, the lawgiver. Church and state are not two separate powers, but a single entity with two aspects related through consonance $(\sigma v v \alpha \lambda \lambda \eta \lambda i \alpha){ }^{43}$

St. Nicholas was also the patron saint of seamen and shipowners. Maintaining the fiscal policy of Nikephoros I (r. 802-811), which was advantageous to shipowners, helped Basil I secure the allegiance of this rising class while also bolstering state finances ${ }^{44}$ Conscious of the growing Arab threat from the sea, Basil also prepared the main fleet, stationed in Constantinople, to defend the capital and created new maritime themata. ${ }^{45}$ St. Nicholas thus connects the central fleet in Constantinople and the principal regional command of the district (thema) of Kibyrraiotai, the location of the city of Myra. ${ }^{46}$ Another important area of imperial propaganda that may have fostered the privileged link with St. Nicholas is philanthropy, which Basil I and his successors nurtured. The episodes from the Life of St. Nicholas include several occurrences of assistance to the poor and needy. ${ }^{47}$

The cult of St. Nicholas was also promoted under Leo Vl, who reinforced the idea of the sacrality of imperial power. In the eulogy for his father, Basil, delivered in 888 , he emphasizes belief in the spiritual gifts of kingship as not far removed from those of the priesthood, a means to bolster his own sacerdotal kingship, making him worth of the legacy of Elijah and Solomon..$^{48}$ Next to honoring St. Nicholas, Leo VI also developed a strong devotion to St. Demetrios, patron saint of Thessalonike and whose relics started exuding myron around the end of the ninth or the early tenth century. ${ }^{49}$

39 Hagios Nikolaos, ed. Anrich, 1:148, chap. 18. For the iconographic cycle, see Nancy P. Ševčenko, The Life of Saint Nicholas in Byzantine Art (Turin: Bottega d'Erasmo, 1972), 104-129; Christopher Walter, The Iconography of Constantine the Great: Emperor and Saint; With Associated Studies (Leiden: Alexandros Press, 2006), 62.

40 Alexander Kazhdan, "An Unnoticed Mention of a Chrysobul Ascribed to Constantine the Great," A

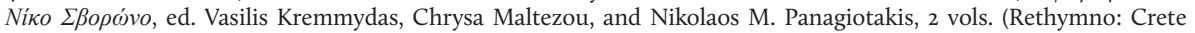
University Press, 1986), 1:135-138.

41 See Paul Magdalino, "Knowledge in Authority and Authorised History: The Imperial Intellectual Programme of Leo VI and Constantine VIl," in Authority in Byzantium, ed. Pamela Armstrong (Farnham: Ashgate, 2013), 206. See also Warren Treadgold, "The Prophecies of the Patriarch Methodius," REB 62 (2004): 235-237; Brubaker, Vision and Meaning, 172.

42 See Zachary Chitwood, "The "Cleansing of the Ancient Laws' under Basil I and Leo VI," in Byzantine Legal Culture and the Roman Legal Tradition, 867-1056 (Cambridge: Cambridge University Press, 2017), chap. 1, 16-44. https://doi. org/10.1017/9781316861547.002.

43 See the discussion in John A. Cotsonis, "The Imagery of Patriarch Methodios I's Lead Seals and the New World Order of Ninth-Century Byzantium," in The Religious Figural Imagery of Byzantine Lead Seals: Studies on the Image of Christ, the Virgin, and Narrative Scenes (Abingdon: Routledge, 2020), chap. 2, 68-69.

44 See Paul Magdalino, "The Merchant of Constantinople," in Trade in Byzantium: Papers from the Third International Sevgi Gönül Byzantine Studies Symposium, ed. Paul Magdalino, Nevra Necipoğlu, and lvana Jevtić (Istanbul: Koç University, 2016), 181-191.

45 Hélène Ahrweiler, Byzance et la mer: La marine de guerre, la politique et les institutions maritimes de Byzance aux VIIle-XVe siècles (Paris: Presses Universitaires de France, 1966), 73-76, 96-99.

46 See Shaun Tougher, The Reign of Leo VI (886-912): Politics and People (Leiden: Brill, 1997), 100.

47 See Jolivet-Lévy, "L'image du pouvoir," 454; Ševčenko, The Life of St. Nicholas in Byzantine Art, 86-90, 151.

48 Riedel, Leo VI and the Transformation of Byzantine Christian Identity, 151-152.

49 See Charalambos Bakirtzis, "Pilgrimage to Thessalonike: The Tomb of St. Demetrios," DOP 56 (2002): 180-183. See

also Franz Alto Bauer, Eine Stadt und ihre Patron: Thessaloniki und der Heilige Demetrios (Regensburg: Schnell \& Steiner, 
Leo $\mathrm{VI}$ acquired myron of the saint and constructed a shrine for him next to the church of the Virgin of the Pharos on the palace grounds. Leo officially integrated the feast of St. Demetrios (October 26) into the imperial calendar. ${ }^{50}$ This was a gesture of thanksgiving for his rehabilitation in 886 just before Basil died, after being disgraced by his father, who had been persuaded that Leo had hatched a plot against him. Appearing to Leo and his mother in a vision, the saint announced their future liberation. ${ }^{51}$ Between St. Nicholas and St. Demetrios, myron thus became an essential element in the imperial cult under the Macedonians..$^{52}$

St. Nicholas acquired renewed prominence in late December 944, when Constantine VII Porphyrogenetos (r. 945-959) took back power from Romanos I Lekapenos (r. 920-944), who had usurped the throne twenty-four years prior. As was the case with Basil I, Constantine VII's grandfather, imperial ideology emphasized the return of order and dignity. The Life of Basil asserts a blood link between Basil and Constantine the Great on Basil's maternal side, , $^{53}$ while St. Nicholas is hailed as first among the hierarchs. ${ }^{54}$ In the De Thematibus, attributed to Constantine VII, Myra is described as the place where the great St. Nicholas, the servant of God, exudes an unguent (myron), which takes its name from the city. 55

\section{Conclusion}

The role of miracle-working myron in shaping the political ideology of the Macedonian Dynasty puts the relationship between church and state in Byzantium in a new light. It provides for symbolic unction of the emperor, both sacerdotal and kingly, while through its baptismal connotation it signifies God's chosen king ruling over his chosen people. At the pilgrimage shrine of Myra, miracle-working myron is accessible to all. Nicholas bestows cures and exorcisms with generosity and efficiency upon everyone, from high state functionaries to peasants.

The Macedonian emperors' attachment to St. Nicholas also allows a recontextualization of imperial ritual in Hagia Sophia and better understanding of its ideological messaging. The incorporation of St. Nicholas's myron flowing shrine at Myra into imperial ideology opened new horizons for the conduct of state policy. As a major port city, Myra offered the capital access to the valuable trade routes of the Mediterranean and better awareness of the sea-based Arab threat. The incorporation of Hagia Sophia into the political and economic framework linking the capital of the empire to Myra brings to the fore the Great Church's role as a stage of the imperial office in Byzantium.

2013), 144, 343-45; John A. Cotsonis, The Religious Figural Imagery of Byzantine Lead Seals II: Studies on Images of the Saints and on Personal Piety (Abingdon: Taylor \& Francis 2020), chap. 3, esp. 128-129.

50 Paul Magdalino, "Saint Demetrios and Leo Vl," Byzantinoslavica 51 (1990): 198-201. Leo Vl also delivered three sermons on St. Demetrios, one of them at the inauguration of his church. Theodora Antonopoulou, The Homilies of the Emperor Leo VI (Leiden: Brill, 1997), 132-136.

51 Tougher, The Reign of Leo VI, 35-36, 59, 96.

52 In the thirteenth century, with the advent of the material anointing of the emperor within the context of the ecclesiastical controversy between the kingdom of Nicea and the principality of Epiros, Archbishop Demetrios Chomatianos used the myron of St. Demetrios to anoint the Epirote ruler; see Apostolos D. Karpozilos, The Ecclesiastical Controversy between the Kingdom of Nicea and the Principality of Epiros, 1217-1233 (Thessaloniki: Thessaloniki University Press, 1973), 84.

53 Vita Basilii, 3.20 and 26.

54 Vita Basilii, 83.11-12.

55 Costantino Porfirogenito: De Thematibus, ed. Agostino Pertusi, Studi e testi 16o (Vatican City: Biblioteca Apostolica Vaticana, 1952), 78 . 